\title{
The Influence of Consumption Values on Housing Furniture Satisfaction among Working Women in Jeddah, Saudi Arabia
}

Makkawi, Fattwo Abdul Rahman, Ahmad Hariza Hashim \& Jasmine Lau Leby

To Link this Article: http://dx.doi.org/10.6007/IJARBSS/v11-i12/11803

DOI:10.6007/IJARBSS/v11-i12/11803

Received: 07 October 2021, Revised: 11 November 2021, Accepted: 28 November 2021

Published Online: 01 December 2021

In-Text Citation: (Makkawi et al., 2021)

To Cite this Article: Makkawi, F. A. R., Hashim, A. H., \& Leby, J. L. (2021). The Influence of Consumption Values on Housing Furniture Satisfaction among Working Women in Jeddah, Saudi Arabia. International Journal of Academic Research in Business and Social Sciences, 11(12), 637-654.

\section{Copyright: @ 2021 The Author(s)}

Published by Human Resource Management Academic Research Society (www.hrmars.com)

This article is published under the Creative Commons Attribution (CC BY 4.0) license. Anyone may reproduce, distribute, translate and create derivative works of this article (for both commercial and non0-commercial purposes), subject to full attribution to the original publication and authors. The full terms of this license may be seen

at: http://creativecommons.org/licences/by/4.0/legalcode

$$
\text { Vol. 11, No. 12, 2021, Pg. } 637-654
$$

Full Terms \& Conditions of access and use can be found at http://hrmars.com/index.php/pages/detail/publication-ethics 


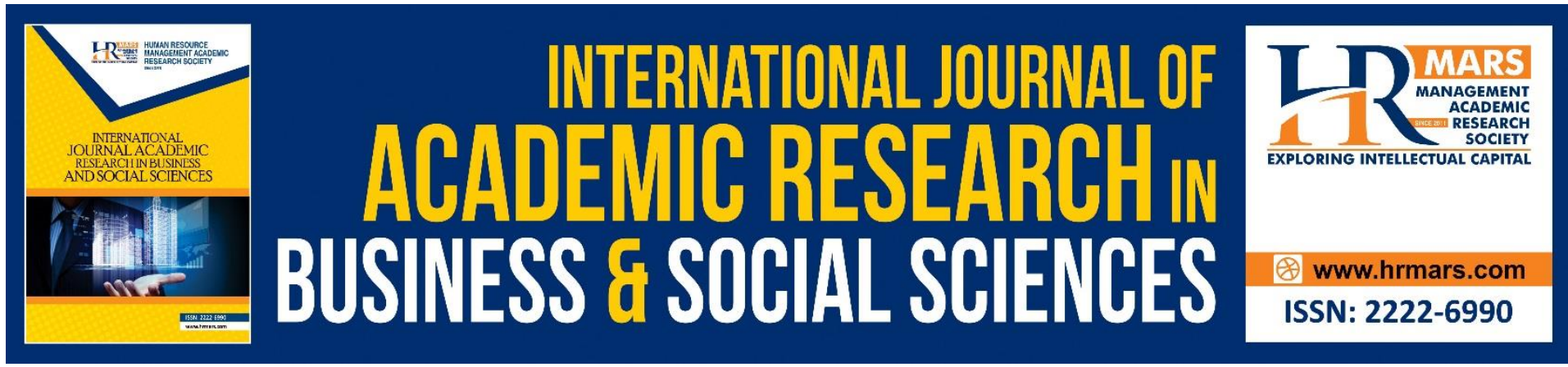

\title{
The Influence of Consumption Values on Housing Furniture Satisfaction among Working Women in Jeddah, Saudi Arabia
}

\author{
Makkawi, Fattwo Abdul Rahman ${ }^{1,2}$, Ahmad Hariza Hashim ${ }^{1}$ \& \\ Jasmine Lau Leby ${ }^{1}$ \\ ${ }^{1}$ Faculty of Human Ecology, Universiti Putra Malaysia, Serdang, Selangor, Malaysia, \\ ${ }^{2}$ Department of Home Economics, Universiti of Bisha, Saudi Arabia
}

Email: ahariza@upm.edu.my

\begin{abstract}
The types and proper arrangement of furniture can assist those who did households chores to perform efficiently and effectively. Thus, it is important especially for working women to be satisfied with their furniture as they come back from work and continue doing home activities. This paper presents the values that influence working women in Jeddah region, Saudi Arabia in their home. Quantitative approach using model of consumption values was adopted for this study. A sample of 350 Saudi working women selected from those working for the government sectors in Jeddah. Questionnaire was sent to these respondents through their respective e-mails. Data collected were later test for normality and reliability and multiple regression analysis was conducted in SPSS to test on the predictors of the consumption values on furniture satisfaction. The results show that, functional, emotional, and conditional values had a significant positive relationship, while social and epistemic values did not show significant relationship with home furniture. Hence, by gaining better insights and understanding of consumption values, it will be able to exhibit and enhance more working women lifestyle in Jeddah, Saudi Arabia and help them achieve work life balance between work and home through the use of home furniture.
\end{abstract}

Keywords: Consumption Values, Home Furniture, Satisfaction, Saudi Working Women, Work Life Balance

\section{Introduction}

Home is the physical structures where people raise families and live comfortably and safely, physically, emotionally and spiritually far from all the distractions of the world (Othman et.al, 2015 \& Handel, 2019). In Saudi Arabia, home is considered a symbol of individuality and selfidentity within society (Almehrej, 2015). Therefore, they decorate their homes in a way that reflects their personality and satisfy their needs (Al-Otaibi, 2006; Al-harkan, 2017). The apartment is a popular housing type among Saudis nowadays especially among Saudi middleclass families with small families (Awliya, 2017; Al harkan, 2017). Due to this development, it necessitates the need to develop furniture that meets the need for this type of housing. Furniture has been described as a moving piece equipment made to assist human in their 
daily activities such as a chair to sit, beds to sleep, and a wardrobe for storing things (Velkova et al., 2019). Another important issue in-relation to types of houses and furniture is that the changes in the family structures, where the number of women going out working is increasing, especially in Jeddah, Saudi Arabia. Traditionally, Saudi women position is initially as a wife, a mother and nurturer to their children, and being responsible for taking care of family members (Fatani, 2008). Their main role is to maintain the structure of the family and performing tasks which include cooking and cleaning, ironing, whereas Saudi men are the breadwinners (Rajkhan, 2014). This mean s that the women will stay at home andi f they were to go out they have to wear hijab and accompanied by others. However, these has changes where the number of women working outside their homes has increased tremendously. According to the statistic on the labor market release for the year 2019 shows that the number of working women in Saudi Arabia have shown a steep increase from $13.4 \%$ in 2009 to $34.6 \%$ in 2019 (General Authority for Statistic, 2019). Majority of Saudi's women works in the public sector organizations, especially in the Ministry of Education and the Ministry of Health (Al Rajhi et al., 2012). However, even though they are working, they still need to play their role as the manager of the house, which includes taking care of the husband's and children's welfare and they also decide what should come in and out from the house. As mentioned by Tawfek (2019), Saudi's women, even if they are career women, they are still responsible for managing home activities, choosing, arranging furniture and determining its arrangement within the home spaces.

These working women spend most of their days during the weekdays working in their workplace and need to do the home activities after coming back from works (Yuhaniz, 2016). Therefore, what needed is something that could help them work at ease when performing their role as housewives and mothers (Priyadarshini \& Behera, 2018). One way of achieving this is by having furniture that that they are satisfied with because it can help reduce the physical stress and overcome the psychological pressures they face when coming back after working long hours at their work place.

Satisfaction with thier furniture is very important since the product might be expensive especially sofa, wardrobe, cupboards and bed and might have some impact on the family finance and also these furniture's will be used for a long time (Khojasteh-Khosro et al., 2020). Therefore, consumer need to choose furniture's that are affordable, comfortable and appropriate for its purpose and at the same time there must be enough space for the furniture, and convenience for the family. One way of ensuring that consumer is satisfied with their decision on having certain products is that the products fulfil the consumer consumption values. Sheth at el. (1991a), suggested that there are five consumption values that could affect consumer satisfaction towards the product they bought. The five values are functional value, emotional value, social value, epistemic value and conditional value. This paper focuses on women because according to Hareri (2018), Saudi's women have more power and a greater role in home than men and they are the one who made decision when it comes to choosing furniture's.

\section{Objectives}

The specific objectives are as below:

1. To examine the level of home furniture satisfaction among Saudi working women in Jeddah. 
2. To examine the relationship between the five consumption values (emotional, social, functional, conditional values and epistemic value) with home furniture satisfaction among Saudi working women in Jeddah.

3. To identify the predictive model for consumption values and home furniture satisfaction among working women in Jeddah.

\section{Literature Review}

\section{House Furniture and Working Women Satisfaction}

Furniture items used in homes varies in styles, sizes and shapes from time-to-time (Oladoyin \& Onwuakpa, 2020). Furniture has been described as a moving piece made to assist human in their daily activities such as a chair to sit, beds to sleep, and a wardrobe for storing things (Hussein, 2021). It is also referring as a functional equipment used for increasing life comfort within spaces where people perform physical, social and cultural activities (Oztop et al., 2008). Home furniture is also seen as among the important factor in the design and arrangement space in the house, and also helps in performing household activities in a more comfortable way (Akyüz et al., 2019). Home furniture is an industry where consumer choose the products that could express themselves, addresses practical issues, and relates to consumer sentiment (Burnsed and Hodges, 2014). Home furniture allow consumers to "dress" their homes, as they do themselves, with fashion and lifestyle brands and products (Hasan, 2019 and Kizito, 2009). Many homeowners refer to their homes furniture as their personal sanctuary, with an emphasis on comfort and safety and it can have evoked deep feelings within the house residents through bonding or achieving "relationships" with certain pieces (Ponder, 2013).

Kizito et al (2012) defined consumer satisfaction with furniture as "the overall contentment felt by the consumer as a result of a furniture product fulfilling the consumers' expectations and needs in relation to the purpose for which the furniture product was purchased". Thus, furniture must meet several criterial to ensure satisfaction to it users: it must be comfortable and fit for purpose, it should be practical for multi-purpose use, there should be enough space for furniture; it should be easy to maintain and, finally, and it should be affordable (Oztop et al., 2008; Nowakowski, 2019).

Saudi women in Jeddah nowadays care about the expression of their identities in choosing furniture and putting their stamp and personal footprint on the home environment. Hareri (2018) stated that even though choosing an ideal piece of furniture can be an exciting activity for women and family, it can also be a complex and stressful activity because of it significant commitment with a long-lasting consequence.

\section{Theory of Consumption Values}

Theory of consumption value has been extensively acknowledged and utilized to predict consumer behaviour (Zailani et al., 2019). According to Sheth's et al. (1991a) the theory of consumption value explains what values consumer's use in deciding whether to buy (or not) a product or service. It can be described as a function of multiple consumption value dimensions in influencing consumer preferences (Candan, et al., 2013; Andleeb, 2016). The usefulness and strength of this theory lie in its simplicity as it is simpler in comprehending customer perceived value through searching its dimensions (Aulia et al., 2016). This model is also excellent in assessing the diverse traits and attributes of products through exploring customers' judgement (Chen et al., 2017). By identifying the values influencing consumers' 
decisions, marketers may be able to appropriate their marketing efforts to the right areas and improve the dismissed values of products (Hur et al., 2012). Therefore, this theory of consumption values is considered one of the most crucial contributors to studies of customer perceived value (CPV) for two reasons. First, the theory explains why consumers choose to buy or not buy a specific product, why consumers choose one product type over another, and why consumers choose one brand over another. Secondly, the theory can be applied to a full range of product types (consumer nondurables, consumer durables, and industrial goods) and services (Sheth et al., 1991b). According to Sheth et al. (1991b), there are five consumption values that affect consumer preference: functional value, emotional value, social value, epistemic value, and conditional value (Fig. 1). This theory rests on three fundamental propositions: (1) consumer choice is a function of multiple consumption values; (2) the values make differential contributions in the choice situation; and (3) the values are independent of each other. Thus, all or any of the consumption values can influence a decision and can contribute additively and incrementally to choice (Long \& Schiffman, 2000).

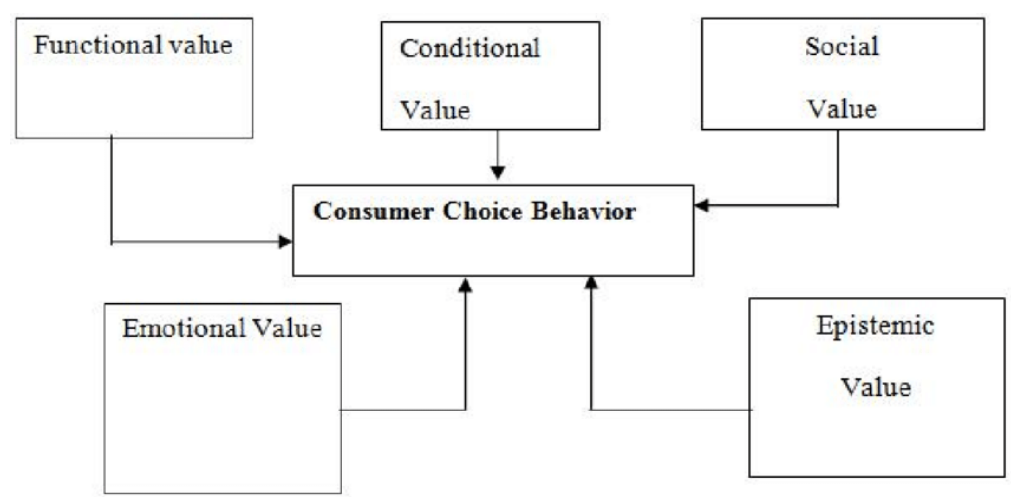

Figure 1: Consumption Values That Affect Consumer Behavior Source: Sheth et al (1991a)

Functional value is the perceived utility acquired from an alternative's capacity for functional, utilitarian, or physical performance. Social value is the perceived utility acquired from an alternative's association with one or more specific social groups. Emotional value is the perceived utility acquired from an alternative's capacity to arouse feelings or affective state. Epistemic value is the perceived utility acquired from an alternative's capacity to arouse curiosity, provide novelty, and/or satisfy a desire for knowledge. Lastly, Conditional value is the perceived utility acquired by an alternative as the result of the specific situation or set of circumstances facing the choice maker (Sheth et al., 1991b). Therefore, this theory will explain on the important values that influence working women in Saudi in their home furniture preferences.

\section{Consumption Values and Housing Furniture Satisfaction (DV) Among Saudi Working Women} The determinants of choosing furniture and furnishings depend on multiple factors and these determinants are the main factors that lead to perceived customer values which could affect their satisfaction in a positive way. To achieve this, researchers have studied the effect of consumption values on customer satisfaction. Most of the results found that perceived value positively affects customer satisfaction (Malik, 2012). Troin (2011) stated that, others factors such as technological, economic, social, and cultural changes could also influence individuals' attitudes and satisfaction towards the adaptation process to the changes in their environment. 
Therefore, consumer choose their furniture that they prefer according to different values to match their lifestyle, comfort, time, energy and money that they have at that point in time (Oztop et al., 2008). Thus, suitability to the needs of the family, availability, right and affordable price, prior knowledge as well as quality and brand awareness are all essential criteria's in fulfilling their preferences for home furniture (Al-Sour, 2019).

\section{Methodology}

Data was collected from different education institutions and health institutions in the public sector within the Jeddah region in Saudi Arabia. According to Ramady, (2013), Saudi working women prefer to work in the public sector either as teachers, lecturers or health professionals. The main reason for many Saudi women chooses to work in these institutions because they believed that they can maintain gender separation easily and fewer gender barriers.

\section{Location of the Study}

Saudi Arabia is the second largest land area within the Middle East and occupies approximately $80 \%$ of the Arabian Peninsula. According to Khubrani el at., (2018), there are total of 13 administrative Provinces in Saudi Aribia and is divided into a number of governorates, Central (Riyadh, Al- Qassim), Northern (Northern borders region, Tabuk, Al-Jwf and Hail), Southern (Asir, Jazan, Bahah and Najran), Eastern (Eastern province) and Western (Mecca and Medina) as can be seen in figure 2 below.

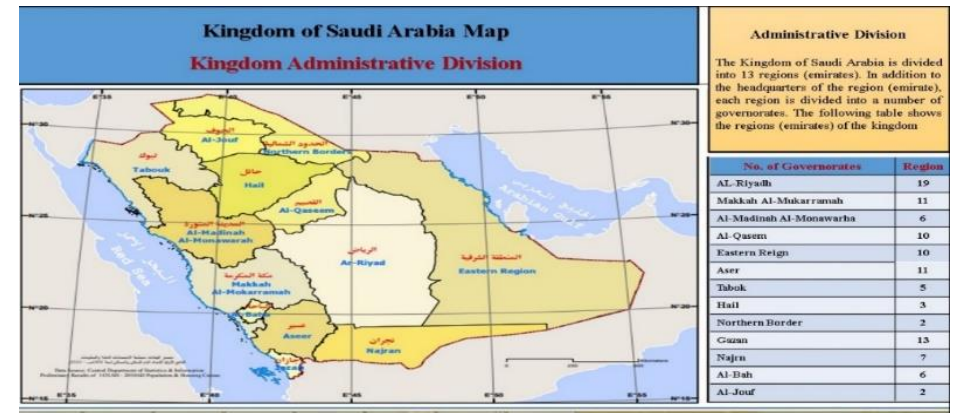

Figure 2: Saudi Arabia, illustrates the kingdom's regions

The administrative division of the Kingdom is divided into a number of governorates with number of regions which varies from one region to another. The region also divided into centre's which linked with the governorate or the Emirate of the region. The population of Saudi Arabia has grown very rapidly since 1980. In1990, the population was $16,139,000$. By the next decade, the population grew by $24.2 \%$ with the total number counted at $20,045,000$ in 2000.The recent estimates for 2010 indicate the total population has grown to 29,195,895. In Mid-year of 2019 the total population has become 34,218,169 with the number of male $19,739,056$ and female 14,479,113 (General Authority for Statistic, 2019).

Jeddah is the second largest city in Saudi Arabia after Riyadh, and it placed in the west side of Hijaz region, through a coastline on the Red Sea, Jeddah are considered as the tourism and economic capital of the Kingdom of Saudi Arabia and is the major urban centre of western Saudi Arabia (Baik et al., 2014). It is the largest city in Makkah Province (Salamah, 2018). The City is also the welcoming port to the two holy cities "Islam of Madinah and Makkah" (Telmesani et al., 2009). 
The total population of Jeddah $3,457,794$ people, with the female total Saudi population in Jeddah is 609,001 (48\% ) (General Authority for Statistics, 2016). The increase in the number of people is due to internal migration from villages to Jeddah seeking job opportunities and better life, causing an increase in housing demand, which forced the state to start providing new housing types such as apartment and build more roads (Al-harkan, 2017). As per Jeddah urban observatory survey carried out in 2018 indicated that Jeddah households living in apartment or floors represented $64.4 \%$ of the housing stock. Most of the housing stock consists of small units. Residential units consisting of one or two bedrooms represent $64.3 \%$ of the total housing stock $19.1 \%$ those with three bedrooms $19.1 \%$; and $16.6 \%$ with larger units (more than three bedrooms) (Ministry of Economy and Planning, 2018).

\section{Target Population}

The population for this study is working women in Jeddah, Saudi Arabia. Based on the data provided by Saudi General Authority for Statistic, 2019, The total number of women who is 15 years or more (married, divorced, and widowed, single) is 609,001 (General Authority for Statistic, 2019).

Looking at the large pool of possible participants, this research narrowed down to target population who meet some pre-set certain criterion. The inclusion and exclusion criteria for the study as shown in Table 1.

Table 1: Inclusion and exclusion criteria

\begin{tabular}{cll}
\hline S/No & Inclusion criteria & Exclusion criteria \\
\hline 1 & Saudi working women who live in Jeddah district only & Saudi working \\
2 & Saudi working women who are living in apartment & women living in \\
3 & $\begin{array}{l}\text { Saudi working women with 2 and above children or family } \\
\text { members }\end{array}$ & Jeddah villages \\
\hline 4 & $\begin{array}{l}\text { Saudi women working in the Education and Health } \\
\text { Institution }\end{array}$ \\
\hline
\end{tabular}

\section{Sampling Techniques}

A multi-stage sampling technique was adopted in identifying the respondents for this study due to the disperse nature of the population. In multi-stage sampling, a hierarchical arrangement of sampling units is made from which the first stage, sampling units $M$ are randomly selected from an initial un-stratified sample. From the sampling units randomly selected, the sampled unit itself is divided into $\mathrm{N}_{\mathrm{i}}$ secondary units and another sample $\mathrm{Ni}$ is as well randomly selected. It must be noted that in multi-stage sampling $\mathrm{Ni}<\mathrm{N}$.

Table 2: Population cluster across Jeddah region

\begin{tabular}{cccc}
\hline Region & University & School & Hospital \\
\hline East & 0 & 183 & 2 \\
North & 1 & 190 & 4 \\
South & 0 & 182 & 2 \\
Middle & 1 & 147 & 6 \\
TOTAL & 2 & 702 & 14 \\
\hline
\end{tabular}


In this study, a two-stage sample is considered. A sample of university, school and hospital were selected from the total of combined number in universities, schools and hospitals in the Jeddah region as shown in the Table 2.

The two universities that exists in Jeddah were selected, and 23 schools were selected from the 702 schools in Jeddah region. In addition, seven hospitals were selected from the 14 hospitals currently in Jeddah region to complete the second stage of the multi-stage sampling. All the selection is across the four regions of Jeddah (North, South, East and West regions). In the final stage, approximately 186 questionnaires were sent to each cluster (universities, schools and hospitals) through the various Saudi working women organizational forums. A total of 356 responses were returned out of 557 distributed.

Table 3: Distribution and Returned questionnaires

\begin{tabular}{clcccc}
\hline No & Cluster & No. & $\begin{array}{c}\text { Distributed } \\
\text { questionnaires }\end{array}$ & $\begin{array}{c}\text { Returned } \\
\text { questionnaires }\end{array}$ & Response rate \\
\hline 1 & University & 2 & 186 & 102 & $55 \%$ \\
2 & School & 23 & 185 & 143 & $77 \%$ \\
3 & Hospital & 14 & 186 & 111 & $60 \%$ \\
\hline Total & & 36 & 557 & 356 & $64 \%$ \\
\hline
\end{tabular}

\section{Questionnaire Design}

The first page of the questionnaire is attached with a cover page bearing the identity and information of the researcher, including the assurance of confidentiality to motivate the respondents to answer the questionnaire. This study is moulded on a structured questionnaire consisting of 53 statements that represented all the variables and close-ended multiple-choice questions. Furthermore, the questionnaire was divided into three sections (demographic information, perceived values, and housing furniture satisfaction).

The first section comprises 8 questions on demographic information of the respondents (age, years married, work sector, education level, total family income, year's married, family members, and number of rooms in the house).

The second section is the independent variables which comprises of 41 statements. The variables are divided into five perceived values that affect the working woman when she chooses home furniture, which is include of value (functional, emotional, social, epistemic, conditional) adapted from (Ponder, 2013; Candan et al., 2013; Alsusi, 2015).

The fourth section is the dependent variables comprises of 4 sentences to understand the extent of the working woman's satisfaction with her choice of home furniture and were adapted from (Chai et al., 2018; Gan and Wang, 2017).

\section{Data Collection Procedure}

Due to the pandemic COVID19 which causes lockdown everywhere, questionnaire was send to the respondents through their respective e-mails. The respondents could answer the questions and e-mail back the responses to the researcher. Both sending and responding became simplified and cost effective. Other benefits were increase in geographical spread of respondents, the response is almost immediate where the respondents can begin 
immediately once they open their email and elimination of time zone hassles for individuals in different geographic areas (Kaputa et al., 2018). Therefore, for the e-mailed survey the following steps were taken: Questionnaires attached with a cover letter through email of the 557 selected working women in Jeddah. In the cover letter, the objective the study was listed and confidentiality of the participants. The respondents were asked to fill - in the questionnaire and returns back to sender's e-mail address within 4 weeks. The survey was conducted during the period from 23 February to 23 July (approximately 20 weeks).

\section{Data Analysis}

\section{Demographic Characteristics of the Respondents}

The respondents were working women in Jeddah, Saudi Arabia. The results of the frequency descriptive analysis for Table 4 below show the statistical information on the demographic characteristics of working women in Saudi Arabia such as age, marital status, marriage, education level, work sector, number of rooms in the house, number of family members and total monthly women income.

Most of the working women participating in this study are in the age group of 34 to 41 years $(38.9 \%)$, married $(58 \%)$ and $46.6 \%$ has been married for 8 years and. In terms of educational level, $60.9 \%$ are with bachelor's degree and $57.2 \%$ with an income of 6000 Riyals or more. In terms of number of rooms in the houses, majority of respondents (64.6\%) own a five rooms apartment and $35.5 \%$ with family size between 4 or 5 members. 
Table 4: Demographic Profile of the Respondents $(n=350)$

\begin{tabular}{|c|c|c|}
\hline Variables & Frequency & $\%$ \\
\hline \multicolumn{3}{|l|}{ Age Group (Years) } \\
\hline $18-25$ & 40 & 11.4 \\
\hline $26-33$ & 92 & 26.3 \\
\hline $34-41$ & 136 & 38.9 \\
\hline 42 and more & 82 & 23.4 \\
\hline \multicolumn{3}{|l|}{ Marital status } \\
\hline Married & 203 & 58 \\
\hline Widowed & 21 & 6 \\
\hline Divorced & 46 & 13.1 \\
\hline Single & 80 & 22.9 \\
\hline \multicolumn{3}{|l|}{ Years of marriage } \\
\hline Not married & 80 & 22.9 \\
\hline $2-3$ years & 26 & 7.4 \\
\hline $4-5$ years & 37 & 10.6 \\
\hline $6-7$ years & 44 & 12.6 \\
\hline 8 years and above & 163 & 46.6 \\
\hline \multicolumn{3}{|l|}{ Education level } \\
\hline High School & 35 & 10 \\
\hline Diploma & 34 & 9.7 \\
\hline Bachelor degree & 213 & 60.9 \\
\hline Postgraduate & 68 & 19.4 \\
\hline \multicolumn{3}{|l|}{ Work sector } \\
\hline General Education & 122 & 34.9 \\
\hline Higher Education & 115 & 33.9 \\
\hline Health & 113 & 32.3 \\
\hline \multicolumn{3}{|c|}{ Number of rooms in the house } \\
\hline 2 Rooms & 4 & 1.1 \\
\hline 3 Rooms & 53 & 15.2 \\
\hline 4 Rooms & 67 & 19.1 \\
\hline 5 Rooms & 226 & 64.6 \\
\hline \multicolumn{3}{|c|}{ Number of family members } \\
\hline $2-3$ & 76 & 21.7 \\
\hline $4-5$ & 124 & 35.5 \\
\hline $6-7$ & 109 & 31.1 \\
\hline 8 and above & 41 & 11.7 \\
\hline \multicolumn{3}{|c|}{ Total monthly women income *(SR) } \\
\hline$\leq 3,000 \mathrm{SR}$ & 26 & 7.4 \\
\hline $3,001-4,000 S R$ & 29 & 8.3 \\
\hline $4,001-5,000 S R$ & 48 & 13.7 \\
\hline $5,001-6,000 S R$ & 47 & 13.4 \\
\hline$>6000 \mathrm{SR}$ & 200 & 57.2 \\
\hline
\end{tabular}

Note:1USD=SR3.75 
Table 5 show that the highest mean was functional value with $(M=4.32 ; S D=0.55)$ out of a maximum 5 making up $86 \%$ which indicated that functional value is the most perceived value associated with home furniture. This is followed by conditional value (4.32), emotional value (4.04) and epistemic value (3.97). While, social value had the lowest mean with 3.93 out of a maximum 5 making up approximately $78 \%$ which indicated that social value is the least associated value with home furniture in Saudi context. For furniture satisfaction, it has a mean value of 4.30. Therefore, the result of this study indicated that most of the respondents are generally satisfied with their home furniture.

Table 5: Descriptive Statistics for Perceived Values Variables

\begin{tabular}{lccccc}
\hline \multicolumn{1}{c}{ Variables } & Minimum & Maximum & Mean & Percent & $\begin{array}{c}\text { Std. } \\
\text { Deviation }\end{array}$ \\
\hline Functional Value & 2.29 & 5.00 & 4.3224 & $86 \%$ & .54615 \\
\hline Emotional Value & 2.00 & 5.00 & 4.0429 & $80 \%$ & .69093 \\
\hline Social Value & 1.25 & 7.50 & 3.9379 & $78 \%$ & .80442 \\
\hline Epistemic Value & 1.25 & 5.00 & 3.9736 & $79 \%$ & .68799 \\
\hline Conditional Value & 2.25 & 5.00 & 4.3207 & $86 \%$ & .56855 \\
\hline $\begin{array}{l}\text { Housing Furniture } \\
\text { Satisfaction }\end{array}$ & 2.58 & 5.00 & 4.3033 & $86 \%$ & .47462 \\
\hline Overall & 2.56 & 5.10 & 4.1195 & $82 \%$ & .45522 \\
\hline
\end{tabular}

\section{Pearson Correlation Analysis}

Pearson correlation coefficients were used to determine on the relationship between independent variables and the dependent variable. The results indicated that are significant relationship for all the independent variables (FV, CV, EV, EPV and SV) as shown in Table 6.

Functional value beta coefficient value is 0.941 with a significant value of 0.001 indicating this value has a strong relationship with working women furniture satisfaction. This finding is similar to the previous researches of (Hussein, 2021; Jošt et al.,2020; Zailani et al., 2019).

While conditional value also shows a positive significant relationship with respondents' furniture satisfaction with coefficient value at 0.635 and $p<0.001$. Emotional value beta coefficient value is 0.395 and with a significant value of 0.001 indicating a positive and significant relationship on respondents' furniture satisfaction. Thus, the finding is in line with prior research of Akyüz et al (2019); Poon (2017) which found that emotional value has significant impact on customer satisfaction. Epistemic value beta coefficient value is 0.325 with $p<0.001$, indicating a positive significant relationship with respondents' furniture satisfaction. This finding is in line with prior study of Oblak et al (2017); Sakpichaisakul (2012) when they found that epistemic value is positively and significantly impact with customer satisfaction. Social value beta coefficient value of 0.215 also at $p<0.001$ again indication a positive significant relationship between respondent's furniture satisfaction. Olgun and Erdoğan (2016) found that there is no significant and least impact of social value on customer satisfaction. However, Akyüz et al (2019); Hareri (2018b); Al-harkan (2017) gave a different result when they found that social value has significant and positive impact on customer satisfaction in their research study. 
Table 6: Correlation Matrix of Independent Variables and Furniture Satisfaction

\begin{tabular}{|c|c|c|c|c|c|c|}
\hline Variables & HFS & FV & EV & SV & EPV & CV \\
\hline $\begin{array}{l}\text { HFS(Home Furniture } \\
\text { Satisfaction) }\end{array}$ & 1 & & & & & \\
\hline FV (Functional Value) & $.941^{* *}$ & 1 & & & & \\
\hline EV (Emotional Value) & $.395 * *$ & $.310 * *$ & 1 & & & \\
\hline SV (Social Value) & $.215^{* *}$ & $.187^{* *}$ & $.332 * *$ & 1 & & \\
\hline EPV (Epistemic Value) & $.325^{* *}$ & $.290 * *$ & $.322 * *$ & $\begin{array}{l}.591 * \\
*\end{array}$ & 1 & \\
\hline CV (Conditional Value) & $.635^{* *}$ & $.477^{* *}$ & $.330 * *$ & $.243^{*}$ & $\begin{array}{l}.306^{*} \\
*\end{array}$ & 1 \\
\hline
\end{tabular}

**. Correlation is significant at the 0.01 level (2-tailed).

\section{Multiple Linear Regression Analysis}

The other important step before running the regression analysis is to examine on the normality of the data. The collected data exhibits a normal distribution judging from the bellshaped curves where the most of the value are within the bell curve with an overall mean value of $(-2.22 \mathrm{E}-15)$ and standard deviation value of 0.993 which lead to infer that the residual (disturbance or errors) are normally distributed.

Test of multicollinearity diagnostic show that there is no evidence of significant multicollinearity among the research predictor variables that is because all tolerance values are above 0.10 , and ranged from 0.602 to 0.931 and also all VIF values are less than 10 and ranged from 1.074 to 1.660 (Sekaran, 2003). Based on the Durbin Watson score of 1.850 shows that it falls in the acceptable range (it should be 1.5 to 2.5 ), indicating that there is no autocorrelation between the residuals (Bakon and Hassan, 2013). Also, the model result for the value of $R$ square is 0.93 indicating that $93 \%$ of the dependent variable changes (women satisfaction with furniture) can be expected by the independent variables, the adjusted $R$ square is 0.933 indicating that the model is appropriate, as the value is greater than 0.60 (Gujarati, 2004). This is interpreted as that $7 \%$ of the variance in furniture satisfaction can be attributed to other variables that were not taken into account in this study. Therefore, the listed five independent variables have better relation with the dependent variable to be the values which affects furniture satisfaction of women

\begin{tabular}{lccccc}
\hline \multicolumn{6}{c}{ Model Summary } \\
\hline Model & $\mathrm{R}$ & R Square & $\begin{array}{c}\text { Adjusted R } \\
\text { Square }\end{array}$ & $\begin{array}{c}\text { Std. Error of } \\
\text { the Estimate }\end{array}$ & Durbin-Watson \\
\hline 1 & $.967^{\mathrm{a}}$ & .934 & .933 & .12268 & 1.850 \\
\hline a. & Predictors: (Constant), mean functional value, mean emotional value, mean \\
social value, mean epistemic value, mean values conditional \\
b. & Dependent Variable: housing furniture satisfaction & \\
\hline
\end{tabular}

Table 7: Model Summary 


\section{Analysis of Variance (ANOVA)}

Analysis of variance (ANOVA) is shown in Table 8 below, the results are statistically significant $[F(5,344)=957.823 p=.000)$ with a $p$-value of less than 0.001 , so any given change in one of the independent variables such as functional value, emotional value, social value, epistemic value and conditional value will always produce a corresponding change in the dependent variable (housing furniture satisfaction), thus all independent variables were confirmed by the analysis to have strong impact on dependent variable.

Table 8: Analysis of Variance (ANOVA)

\begin{tabular}{lllllll}
\hline Model & & $\begin{array}{l}\text { Sum of } \\
\text { Squares }\end{array}$ & df & $\begin{array}{l}\text { Mean } \\
\text { Square }\end{array}$ & $F$ & Sig. \\
\hline \multirow{2}{*}{1} & Regression & 73.438 & 5 & 14.688 & 975.823 & .000 \\
\cline { 2 - 7 } & Residual & 5.178 & 344 & .015 & & \\
\cline { 2 - 7 } & Total & 78.616 & 349 & & & \\
\hline
\end{tabular}

\section{Multiple Regression Coefficients}

Multiple Regression coefficient beta was used to determine the predictive ability of functional value, emotional value, social value, epistemic value, and conditional value on furniture satisfaction. Regression Model consists of five predicting variables namely; functional value $(\mathrm{X} 1)$, emotional value (X2), social value (X3), epistemic value (X4), and conditional value (X5) regressed with furniture satisfaction as shown in the equation below:

$\hat{Y}=b 0+b 1 F V+b 2 E V+b 3 S V+b 4 E P V+b 5 C V+e i$.

Conditional value beta coefficient value is 0.189 and with a significant value of 0.000 which is lower than 0.05 . Hence, conditional value is found to has a positive and significant impact on customer satisfaction. Moghimi et al. (2017) have done a similar research and found that conditional value has significant impact on level of customer satisfaction.

Table 9: Multivariate Regression Coefficients with Housing Furniture Satisfaction (HFS) As Dependent Variable

\begin{tabular}{|c|c|c|c|c|c|c|c|}
\hline \multirow[b]{2}{*}{ Model } & \multicolumn{2}{|c|}{$\begin{array}{l}\text { Unstandardi } \\
\text { zed } \\
\text { Coefficients }\end{array}$} & \multicolumn{3}{|c|}{$\begin{array}{l}\text { Unstandardiz } \\
\text { ed } \\
\text { Coefficients }\end{array}$} & \multicolumn{2}{|c|}{$\begin{array}{l}95.0 \% \\
\text { Confidence } \\
\text { Interval for B }\end{array}$} \\
\hline & B & $\begin{array}{l}\text { Std. } \\
\text { Error }\end{array}$ & Beta & $\mathrm{t}$ & Sig. & $\begin{array}{l}\text { Lower } \\
\text { Bound }\end{array}$ & $\begin{array}{l}\text { Upper } \\
\text { Bound }\end{array}$ \\
\hline (Constant) & .260 & .064 & & 4.043 & .000 & .134 & .387 \\
\hline Functional Value(FV) & .705 & .014 & .811 & 50.13 & .000 & .677 & .733 \\
\hline Emotional Value(EV) & .049 & .011 & .072 & 4.639 & .000 & .029 & .070 \\
\hline Social Value (SV) & $\begin{array}{l}- \\
.012\end{array}$ & .010 & -.021 & -1.180 & .239 & -.032 & .008 \\
\hline $\begin{array}{l}\text { Epistemic } \\
\text { (EPV) }\end{array}$ & .006 & .012 & .009 & .522 & .602 & -.018 & .031 \\
\hline Conditional Value & .189 & .014 & .227 & 13.89 & .000 & .163 & .216 \\
\hline
\end{tabular}

(CV)

a. Dependent Variable: Housing Furniture Satisfaction(HFS) 
Overall, the result of regression analysis indicated that only functional value, conditional values, and emotional value were found to have significant impact on working women satisfaction of home furniture. The other two indicators of consumer perceived values (CPV) (social value and epistemic value) have found to be not significant on working women satisfaction for home furniture. Table 9 shows a summary of the results related to all hypotheses tested.

The estimated multiple linear regression equation is as follows

$\hat{\mathrm{Y}}=\mathrm{b} 0+\mathrm{b} 1 \mathrm{X} 1+\mathrm{b} 2 \mathrm{X} 2+\mathrm{b} 3 \mathrm{X} 3+\mathrm{b} 4 \mathrm{X} 4+\mathrm{b} 5 \mathrm{X} 5+\mathrm{ei}$

$\mathrm{HFS}=0.260+(0.705) \mathrm{FV}+(0.049) \mathrm{EV}+(0.189) \mathrm{CV}$

\section{Conclusion}

The findings from the multiple regression analysis indicated that functional, emotional and conditional values had significantly positive influence on housing furniture satisfaction, while social value and epistemic value has no significant influence on housing furniture satisfaction among working women in Jeddah, Saudi Arabia. Thus, the result of the regression analysis indicated that only conditional value and functional values that prediction for furniture satisfaction among Saudi women. The outcome of this study contributes to women workers and women in general in Saudi Arabia with a clearer understanding of prominent factors that have a significant influence on furniture that make them satisfied in Saudi Arabia house. Hence, by gaining better insights and understanding of perceived values, which is will be able to exhibit and enhance more women lifestyle and making them balance between work and home.

The Saudi Arabia Ministry of work should pay more attention and focus more on women workers aspects with a vision to enhance and improve their satisfaction by providing practical solutions that can make them balance between life and homework. The relevant ministries should provide and facilitate all programs and equipment such as furniture, transport,..etc. that enable women workers to enhance their satisfaction Furthermore, all furniture manufacturing should create and provide a new machine or furniture it is in line with the needs of working women in Saudi Arabia, on the other hand, should establish a conducive competitive environment to allow firms to be more proactive in initiatives and taking more risks by creating new products/services and establishing new furniture products. In addition, the Saudi government should take care of women workers in the plan of work and in the future vision, and that by making special time to them that makes them be comfortable and satisfied in their life. The findings would help families, government, to understand women workers needs and providing them tested outcomes on some intangible resources and determinants of satisfaction for them to better comprehend the influences of perceived values on improving house furniture satisfaction. Moreover, the findings could help the furniture manufacturers to develop some furniture that can help women workers in the future.

\section{References}

Akyüz, I., Ersen, N., Akyüz, K. C., \& Bayram, B. Ç. A. (2019). Research On The Effects Of Demographic And Socio-economic Status Factors On Consumer Preferences In Furniture Purchase (Case Of Black Sea Region). Wood Industry and Engineering, 1(2), 63-76.

Al Harkan, L. S. (2017). Housing Morphology, Gender, and Family Relationships in Jeddah, KSA (1940-2017), PhD. Thesis, University of Cincinnati. 
Al Rajhi, A., Al Salamah, A., Malik, M., \& Wilson, R. (2012). Economic Development in Saudi Arabia. Routledge.

Almehrej, M. I. (2015). A design guide for contemporary Saudi Arabian homes in Riyadh (Doctoral dissertation, North Umbria University).

Al-Nsour, I. (2019). The Targeting Degree of Saudi Women in The Purchasing Decision Process. Probe-Business Management, 1(1). doi: 10.18686/bm.v1i1.1125

Al-Otaibi, A. (2006). The aspiration for housing in Jeddah - Saudi Arabia. Journal of Postgraduate Studies in Architecture, Planning and Landscape, 6, 6-11.

Alsusi, R. (2015). The effect of design flexibility on housing utilization efficiency in the Gaza strip (with reference to multi-functional interior spaces. (Master thesis). Gasa University.

Andleeb, N. (2016). Brand Loyalty And Consumption Values: Empirical Analysis Of Personal Care Products. Arabian Journal of Business and Management Review (Oman Chapter), 6(5)

Baik, A., Alitany, A., Boehm, J., \& Robson, S. (2014). Jeddah Historical Building Information Modelling" JHBIM"-Object Library. International Society for Photogrammetry and Remote Sensing (ISPRS), (II)5, $23-25$.

Bakon, K.A., \& Hassan, Z., (2013). Perceived Value of Smartphone and Its Impact on Deviant Behaviour: An Investigation on Higher Education Students in Malaysia. International Journal of Information System and Engineering. [e-journal]. Available t:http://www.academia.edu/8075984.

Baper, S. Y., \& Saied, A. R. (2019). Small Spaces Need Smart Solutions: Impacts Of Smart Interior Design Solutions On Achieving Flexible Spaces. International Transaction Journal of Engineering, Management, \& Applied Sciences \& Technologies, 11(6). ISSN 2228-9860

Burnsed, K. A., \& Hodges, N. J. (2014). Home furnishings consumption choices: a qualitative analysis. Qualitative Market Research: An International Journal.

Candan, B., Ünal, S., \& Erciş, A. (2013). Analysing the relationship between consumption values and brand loyalty of young people: A study on personal care products. Management, $29,46$.

Chen, L. L., Basit, A., \& Hassan, Z. (2017). The Impact of Customer Perceived Value on Customer Satisfaction: A Study on Malaysian Automobile Industry. International Journal of Accounting \& Business Management, 5 (1), 93-110.

Choi, C., Greenwell, T. C., \& Lee, K. (2018). Effects of service quality, perceived value, and consumer satisfaction on behavioral intentions in virtual golf. Journal of Physical Education and Sport, 18(3), 1459-1468.

Fadlallah, S. M. H. (2013). The Role of a Woman. Bayynat. Retrieved from http://english.bayynat.org/WomenFamily/woman1.htm.

Fatani, E. M. S. (2008). Impact of End-Stage Renal Failure on the Everyday Life of Saudi Arabian Women. University of Surrey Department of Sociology.

Gan, C., \& Wang, W. (2017). The influence of perceived value on purchase intention in social commerce context", Internet Research, 27(4),772-785.

General Authority for Statistics. (2016). Kingdom of Saudi Arabia population. Retrieved from http://stats.gov.sa.

General Authority for Statistics. (2019). Kingdom of Saudi Arabia population. Retrieved from http://stats.gov.sa.

Gujarati, D.N. (2004) Basic Econometrics. 4th Edition, McGraw-Hill Companies

Handel, A. (2019). What's in a home? Toward a critical theory of housing/dwelling. Environment and Planning C: Politics and Space, 37(6), 1045-1062. https://doi.org/10.1177/2399654418819104 
Hareri, R. H. (2018a). Contemporary home environment in Jeddah City: women and the design of living spaces. Thesis (PhD), University of Edinburgh.

Hareri, R. H. (2018b). Saudi Women and the Expression of Identity in the Domestic Living Space. Humanities and Social Sciences, 7-11. doi: 10.11648/j.hss.20180601.12

Hasan, E. F. E. (2019). "Basic Design Is Mother Of Design” And Furniture Design. The XXIXTH International Conference Research for Furniture Industry At: Gazi University, Ankara.(p. 279).

Hur, W. M., Yoo, J. J., \& Chung, T. L. (2012). The consumption values and consumer innovativeness on convergence products. Industrial Management \& Data Systems, 112(5), 688-706.

Hussein, H. A. (2021). Multifunctional Furniture as a Smart Solution for Small Spaces for the Case of Zaniary Towers Apartments in Erbil City, Iraq. International Transaction Journal of Engineering, Management, \& Applied Sciences \& Technologies, 12(1), 12A1H, 1-11. http://tuengr.com/V12/12A1H.pdf DOI: 10.14456/itjemast.2021.8

Chamber, J. (2017). facts and figures, annual report in Jeddah 2016-2017. https://jeg.org.sa/sites/default/files/library/files/FF-AR-16012018.pdf

Jošt, M., Kaputa, V., Nosál'ová, M., Barčić, A. P., Perić, I., \& Oblak, L. (2020). Changes in customer preferences for furniture in Slovenia. Drvna Industrija, 71(2), 149-156. https://doi.org/10.5552/drvind.2020.1967

Kaputa, V., Barčić, A. P., Mat́ová, H., \& Motik, D. (2018). Consumer preferences for wooden furniture in Croatia and Slovakia. BioResources, 13(3), 6280-6299.

Khojasteh-Khosro, S., Shalbafan, A., \& Thoemen, H. (2020). Preferences of furniture manufacturers for using lightweight wood-based panels as eco-friendly products. European Journal of Wood and Wood Products, 1-11.

Khubrani, Y. M., Wetton, J. H., \& Jobling, M. A. (2018). Extensive geographical and social structure in the paternal lineages of Saudi Arabia revealed by analysis of $27 \mathrm{Y}$ STRs. Forensic Science International: Genetics, 33, 98-105.

Kizito, S. (2009). Consumer satisfaction with solid wood furniture produced by small scale enterprises in Uganda.

Kizito, S., Banana, A. Y., Buyinza, M., Kabogozza, J. R. S., Kambugu, R. K., Zziwa, A., \& Sseremba, O. E. (2012). Consumer satisfaction with wooden furniture: an empirical study of household products produced by small and medium scale enterprises in Uganda. Journal of the Indian Academy of Wood Science, 9(1), 1-13.

Long, M. M. \& Schiffman, L. G. (2000). Consumption Values And Relationships: Segmenting The Market For Frequency Programs, Journal Of Consumer Marketıng, 17 (3), 214-232.

Malik, S. U. (2012). Customer satisfaction, perceived service quality and mediating role of perceived value. International Journal of Marketing Studies, 4(1).

Mashhour, A. (2011). The Positive effects of Interior Design for Human Psychological Health. 10.13140/RG.2.1.2936.2168.

Ministry of Economy and Planning (2018). The Statistical Year Book for Kingdom of Saudi Arabia. Riyadh: https://www.stats.gov.sa/en/46.

Moghimi, V., Jusan, M. B. M., Izadpanahi, P., \& Mahdinejad, J. (2017). Incorporating User Values Into Housing Design Through Indirect User Participation Using MEC-QFD Model. Journal of Building Engineering, 9, 76-83. https://Doi.Org/10.1016/J.Jobe.2016.11.012

Nowakowski, P. (2019). Ergonomic Shaping of Functional and Spatial Program of Housing. In International Conference on Applied Human Factors and Ergonomics (pp. 208-217). Springer, Cham. 
Oblak, L., Pirc Barčić, A., Klarić, K., Kitek Kuzman, M., \& Grošelj, P. (2017). Evaluation of factors in buying decision process of furniture consumers by applying AHP method. Drvna Industrija: Znanstveni Časopis Za Pitanja Drvne Tehnologije, 68(1), 37-43.

Oladoyin, L., \& Onwuakpa, L. E. (2020). The Importance of Wood in Home Furniture and Interior Decoration. Awka Journal of Fine and Applied Arts, 6(2).

Olgun, R., \& Erdoğan, R. (2016). Urban furniture and user satisfaction: The example of AntalyaGulluk avenue. Journal of the Faculty of Forestry Istanbul University, 66(2), 674-682.

Othman, Z., \& Aird, R., \& Buys, L. (2015). Privacy, modesty, hospitality, and the design of Muslim homes: A literature review. Frontiers of Architectural Research, 4(1), 12-23.

Oztop, H., Erkal, S., \& Gunay, G. (2008). Factors Influential in Consumers' Furniture Selection and their Preferences regarding Product Features. The International Journal of Interdisciplinary Social Sciences, 23-34.

Ponder, N. (2013). Consumer Attitudes and Buying Behavior for Home Furniture. Report prepared for the Furniture Outreach Program at Franklin Furniture Institute, Starkville, Mississippi, USA.

Poon, S. (2017). The Role of Minimalist Aesthetics in Influencing Consumer Preferences for Furniture Design. New Design Ideas, 1(1),50-58.

Priyadarshini, V., \& Behera, B. (2018). A comparative study on home management practices among working and non-working women in Rourkela City, Sundergarh, Odisha. International Journal of Applied Home Science. ISSN : 2394-1413

Rajkhan, S. (2014). Women in Saudi Arabia: Status, rights, and limitations. (Master Dissertation). University of Washington Bothell.

Ramady, M. A. (2010). The Saudi Arabian economy: Policies, achievements, and challenges. Springer Science \& Business Media.

Sakpichaisakul, T. (2012). Consumer Behavior in Purchasing Home Furnishing products in Thailand. Graduate School of Commerce Waseda University.

Salamah, S. (2018). The quality of life, social care and family relationships of older unmarried Saudi women living in Jeddah: a qualitative study (Doctoral dissertation, University of Surrey).

Sekaran, U., \& Bougie, R. (2003). Research methods for business: A skill building approach. John Wiley \& Sons.

Sheth, J. N., Newman, B. I. \& Gross, B. L. (1991a). Consumption Values and Marketing Choices. South-Western Pub.

Sheth, J. N., Newman, B. I. \& Gross, B. L. (1991b). Why We Buy What We Buy: A Theory of Consumption Values. Journal of Business Research, 22, 159-170.

Tawfek, S. A. (2019). The Manner of Selecting Furniture and Its Supplements and Its Relation to $s$ and Its Relation to Marital Success Predictors in a Sample of Girls Who Will Marry. The Journal of Specific Education Research.

Telmesani, A., Sarouji, F., \& Adas, A. (2009). Old Jeddah: A Traditional Arab Muslim City in Saudi Arabia, 1st ed. ed. King Fahad national library, Jeddah.

Troian, D. (2011). Furniture industry: The consumer furniture preferences in different markets. University of Trento. Retrieved Feb, 26, 2014.

Velkova, A., Sandeva, V., \& Despot, K. (2019). Multi-functional furniture in the overcrowded living area. International Conference for Students And Young Scientists

Yuhaniz, M. B. (2016). House Design Preferences of Malay Housewives in Bandar Tenggara, Johor. 
INTERNATIONAL JOURNAL OF ACADEMIC RESEARCH IN BUSINESS AND SOCIAL SCIENCES

Vol. 11, No. 12, 2021, E-ISSN: 2222-6990 @ 2021 HRMARS

Zailani, S., Iranmanesh, M., Sean Hyun, S., \& Ali, M. H. (2019). Applying the theory of consumption values to explain drivers' willingness to pay for biofuels. Sustainability, 11(3), 668. 